\title{
Final disposal of radioactive waste
}

\author{
H. Freiesleben \\ Institute for Nuclear and Particle Physics, Technische Universität Dresden \\ D-01062 Dresden, Germany
}

\begin{abstract}
Summary. - In this paper the origin and properties of radioactive waste as well as its classification scheme (low-level waste - LLW, intermediate-level waste - ILW, high-level waste - HLW) are presented. The various options for conditioning of waste of different levels of radioactivity are reviewed. The composition, radiotoxicity and reprocessing of spent fuel and their effect on storage and options for final disposal are discussed. The current situation of final waste disposal in a selected number of countries is mentioned. Also, the role of the International Atomic Energy Agency with regard to the development and monitoring of international safety standards for both spent nuclear fuel and radioactive waste management is described.
\end{abstract}

\section{1. - Introduction}

Nuclear energy is set free by the process of controlled nuclear fission and is used for generating electricity in nuclear-power plants. Apart from the safety aspect of nuclearpower plants, the as yet unsolved problem of final disposal of radioactive waste from these plants is a main reason why sections of the public question or even oppose the peaceful utilisation of nuclear energy. There is a sense of unease among laymen whenever 
TABLE I. - Anthropogenic radionuclides; NWT: Fission product from nuclear weapons testing; NR: Fission product from nuclear reactors.

\begin{tabular}{lll}
\hline Symbol & Half-life & Source \\
\hline H-3 & $12.3 \mathrm{a}$ & NWT, NR, reprocessing, nuclear weapons manufacturing \\
Sr-90 & $28.78 \mathrm{a}$ & NWT, NR \\
Tc-99 & $2.11 \cdot 10^{5} \mathrm{a}$ & Decay product of Mo-99, used in medical diagnoses \\
I-129 & $1.57 \cdot 10^{7} \mathrm{a}$ & NWT, NR \\
I-131 & $8.04 \mathrm{~d}$ & NMT, NR, used for medical treatment \\
Cs-137 & $30.17 \mathrm{a}$ & NWT, NR \\
Pu-239 & $2.41 \cdot 10^{4} \mathrm{a}$ & produced by neutron capture on U-238 \\
\hline
\end{tabular}

radioactivity is involved as this phenomenon cannot be perceived by our senses because it is an abstract concept:

Radioactivity is the phenomenon of spontaneous disintegration or decay of an atomic nucleus (radionuclide) by the emission of particles $(\alpha, \beta)$, usually accompanied by electromagnetic radiation/photons $(\gamma) . \alpha, \beta, \gamma$ particles constitute ionising radiation. Nuclear fission is accompanied by the emission of $\beta, \gamma$ particles as well as neutrons.

Thus, radioactivity itself is not a concrete object; however, the radioactive material is. Nature is full of "naturally occurring radiaoactive material" (NORM; for details see, e.g., ref. [1]) which has been part of our solar system since its formation (primordial origin $\left({ }^{1}\right)$ : K-40 (half life: $\left.T_{1 / 2}=1.28 \cdot 10^{9} \mathrm{a}\right)$, Th-232 $\left(1.41 \cdot 10^{10} \mathrm{a}\right), \mathrm{U}-235\left(7.04 \cdot 10^{8} \mathrm{a}\right)$, $\mathrm{U}-238\left(4.47 \cdot 10^{9} \mathrm{a}\right)$ ) — with the radioactive noble gas radon as progeny of the latter three which seeps out of the soil-or is produced continuously by interactions of cosmic rays with atoms in the atmosphere (cosmogenic origin: H-3 (12.3 a), Be-7 (53.28 d), C-14 $(5730 \mathrm{a})$ ). Hence it is fair to say that radioactivity is and has been a constant companion of mankind. The third component is due to human activity (anthropogenic origin), that is, first of all testing of nuclear weapons, then controlled nuclear fission in nuclear reactors and, finally, artificially produced radionuclides used for industrial processes and medical diagnoses and/or for medical treatment. Table I lists the anthropogenic radionuclides which are a major concern.

Radioactive waste does not include the so called "technologically enhanced naturally occurring radioactive material" (TENORM). This term refers to the enrichment of potassium, thorium, uranium and their progenies in various technical processes and industrial sectors, which do not add to the natural radioactive inventory. Examples are: uranium overburden and mine spoils; phosphate industrial waste; phosphate fertilisers and potash;

$\left({ }^{1}\right)$ In the field of radiation science nuclides are denoted by, e.g., K-40 in contrast to the notation ${ }^{40} \mathrm{~K}$ used in nuclear physics. The former notation is used in this paper. 
coal ash; oil and gas production scale and sludge; water treatment sludge; metal mining and processing waste; geothermal energy production waste; the paper and pulp industry. For further information and details see refs. [2-4]. TENORM is not considered waste; it is either recycled where appropriate or disposed of properly in dedicated repositories.

There is an unquestionable and univocal consensus on the fact that a country utilising nuclear energy for electricity generation, or nuclear reactors for research or radionuclides for medical diagnoses and/or for medical treatment or technical processes leading to TENORM, is ethically and legally responsible for the disposal of radioactive waste and for TENORM. That is, it is the country's responsibility that no harm is done to the biosphere- proper disposal sites are mandatory.

\section{2. - Classification of radioactive waste $\left({ }^{2}\right)$}

The International Atomic Energy Agency introduced a classification scheme for radioactive waste which is used worldwide. It is based on levels of exclusion (clearance) and exemption for every single radionuclide set by the IAEA [7]. These clearance levels were either approved or, as in the case of Germany, tightened by the regulatory authorities of the participating parties in IAEA. Figure 1 shows a graphical representation of this classification scheme. The figures refer to examples of disused sealed sources; the range of NORM is given.

Exempt waste (EW): It meets the criteria for clearance, exemption or exclusion from regulatory control for radiation protection purposes.

Very short-lived waste (VSLW): It is stored for a limited period of up to a few years until the VSLW has decayed; after that it is cleared from regulatory control and open to uncontrolled disposal, use or discharge. Waste contains primarily short-lived radionuclides often used in research and medical diagnoses and/or for medical treatment.

Very low-level waste (VLLW): It does not require a high level of containment and isolation; suitable for disposal in near surface landfill type facilities (refuse dumps) with limited regulatory control. It consists of material whose level of radioactivity is considered non-harmful to the biosphere. It contains e.g. demolished material (concrete, bricks, piping, valves) produced during replacement or dismantling operations on nuclear industrial sites. TENORM also belongs to this category.

Low-level waste (LLW): Waste above clearance level, but with limited amounts of long-lived radionuclides. It requires robust isolation and containment for periods of up to several hundred years and is suitable for disposal in engineered near-surface facilities. LLW is produced by hospitals, industrial processes, and the nuclear fuel cycle. No shielding is required during handling and transport. The volume of LLW is often reduced by compaction or incineration before disposal. LLW comprises about $90 \%$ of the volume of all radioactive waste but only $1 \%$ of its radioactivity.

$\left({ }^{2}\right)$ This chapter is based on publications by the International Atomic Energ Agency, IAEA [5] and the World Nuclear Association, WNA [6]. 


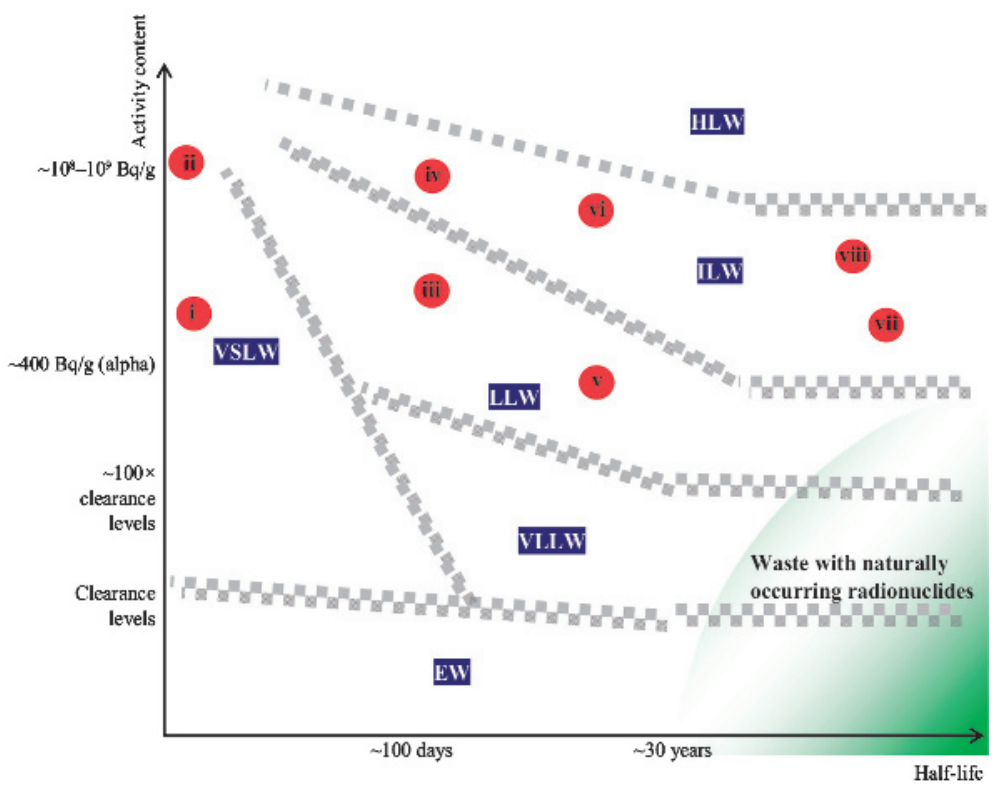

Fig. 1. - IAEA classification scheme for radioactive waste. EW: exempt waste; VSLW: very short-lived waste; VLLW: very low-level waste; LLW: low-level waste; ILW: intermediate-level waste; HLW: high-level waste; the range of waste with naturally occurring radioactive material is given; figures refer to examples of disused sealed sources. Source: [5].

Intermediate-level waste (ILW): Waste that, because of its content, particularly of long-lived radionuclides, requires a greater degree of containment and isolation than that provided by near-surface disposal. This is why disposal at greater depth is required. ILW requires no (or only limited) provision for heat dissipation during storage and disposal. In order to be classed in this category the generated heat load must not exceed $200 \mathrm{~W} / \mathrm{m}^{2}$ on the walls of the emplacement chamber; there, the temperature increase must not exceed $3 \mathrm{~K}$. ILW contains radioactive material such as chemical sludge, resins, fuel cladding, or contaminated material from reactor decommissioning. Smaller pieces and any non-solid material can be solidified in bitumen or concrete for disposal. ILW accounts for about $7 \%$ of the volume of all radioactive waste and contains about $4 \%$ of its radioactivity.

High-level waste (HLW): Waste with levels of activity which are high enough to generate significant quantities of heat through radioactive decay or waste containing large amounts of long-lived radionuclides. Disposal in deep, stable geological formations usually several hundred metres below the surface is the generally accepted option for disposal of HLW. HLW contains the "ash" from "burning" uranium; it comprises fission products, plutonium, and the so-called minor actinides (MA; neptunium, americium, curium) generated in the reactor core. It is highly radioactive and hot (heat load higher than $200 \mathrm{~W} / \mathrm{m}^{2}$ on the walls of the emplacement chamber), and thus it requires cooling as well as shielding. HLW represents more than $95 \%$ of the radioactivity produced in the pro- 
cess of fission in nuclear-power plants for electricity generation or in reactors dedicated to research. HLW can be further divided into the spent fuel itself and the separated waste from the reprocessing of spent fuel. This distinction is important for management and disposal of HLW and will be discussed later.

\section{3. - Conditioning and storage of radioactive waste}

Radioactive waste - by dedicated processes - is converted into a form which is suitable for its subsequent management, i.e. transport, storage and final disposal. Two main goals are to be achieved. The first one is the minimisation of the waste volume. This is achieved by compaction or incineration particularly applied to LLW. Of course, the amount of radioactivity is not changed by this process, only the activity per volume is increased. Compaction is a well-developed and reliable technology used for voluminous solid LLW. Hydraulic pressures up to $50 \mathrm{MPa}$ are applied for compaction, volume reduction factors of up to a factor of 10 are achieved [8].

Incineration of combustible (radioactive) material takes place in specially engineered kilns at temperatures of up to $1000^{\circ} \mathrm{C}$ [9]. Gases produced during incineration are filtered; particulate material and ash from incineration is further conditioned.

The second goal of conditioning of radioactive waste is to reduce its potential hazards by converting it into a stable solid form that is insoluble and immobilises the radionuclides to prevent their migration into the biosphere. It also provides containment to ensure safe handling of the waste. An often practised method is cementation or bitumisation: ILW (solid material, ash, slag, slugde, etc.) is placed in a container. A specially formulated grout is added, mixed, and allowed to solidify. The result is a monolithic block of concealed waste which is then ready for transport, storage and final disposal. An in-drum mixer arrangement inside a hot-cell [10] is shown in the left half of fig. 2 together with a cutaway displaying conditioned HLW in a stainless-steel container (simulation [11]).

HLW originating from reprocessing of spent nuclear fuel is immobilised through the formation of an insoluble solid waste via vitrification. For this purpose, liquid borosilicate glass is loaded with this HLW. After solidification the canisters are welded closed and decontaminated to remove possible surface contamination. Then, they are suitable for transport, storage and final disposal. The right half of fig. 2 shows a glass discharge in the Karlsruhe vitrification plant (VEK) [12] with a cutaway displaying conditioned ILW in a stainless-steel canister (simulation [11]).

Alternative processes which make use of ceramics were developed which also yield the desired quality with regard to containment and immobilisation; an example is the so-called synroc, a synthetic rock [13].

As long as repositories for the final disposal of radioactive waste are not operational, the conditioned waste must be safely transported to and stored at interim storage facilities many of which have been operational worldwide for many years. For both purposes, special casks were constructed meeting the highest requirements with regard to mechanical stability and avoidance of leakage of radioactive material. The integrity and safety of LLW, ILW and HLW must be ensured during storage for an extended period of time, 

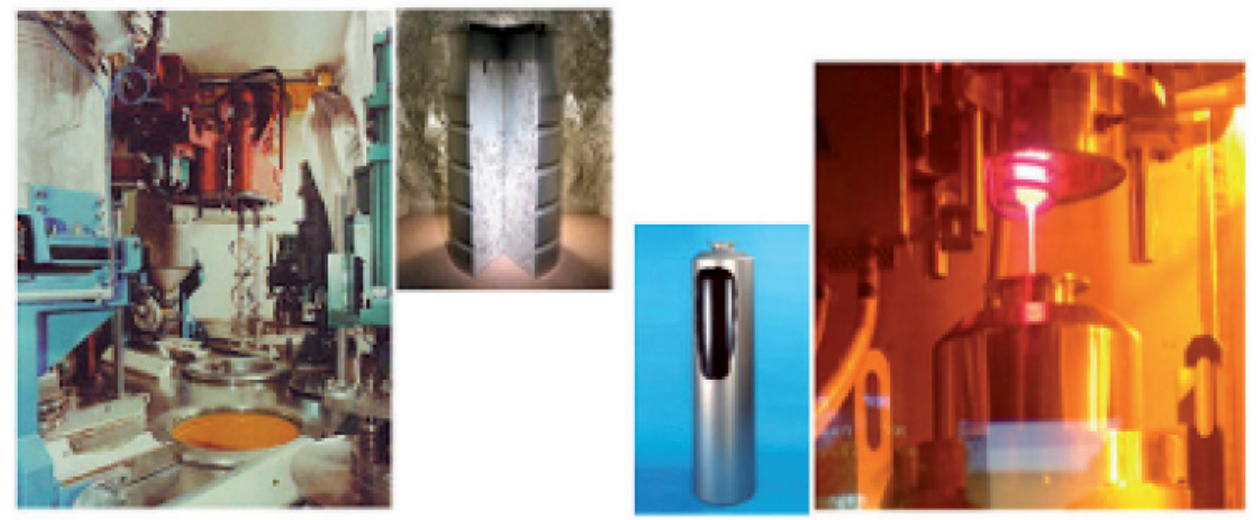

Fig. 2. - Left part: Hot-cell with in-drum mixer arrangement [10] and cutaway displaying conditioned ILW in a stainless-steel container (simulation [11]). Right part: Glass discharge in the Karlsruhe vitrification plant (VEK) [12] and cutaway showing vitrified HLW in a stainlesssteel container (simulation [11]).

which may mean more than 50 years, while geological repositories are being developed. The left frame of fig. 3 shows the interim storage of LLW/ILW by COVRA at Borssele, The Netherlands [14].

Care must also be taken when handling spent fuel elements as a whole. After discharge from a reactor the fuel elements, which are highly radioactive and hot due to the decay heat, need to cool down in water ponds (usually located at the reactor site) for a time. The length of that period of time depends on the characteristics of fuel elements after burn-up and may take 20 to 30 years. After an appropriate decay period, the spent fuel elements are safely packed in dry casks that are put up at interim storage facilities. There, further cooling is provided by forced, or preferably, natural convection driven by the heat radiating from the dry cask. For example, the right frame of fig. 3 displays an array of dry casks at the German interim storage facility of Gorleben [15] awaiting final disposal. Alternatively, spent fuel elements are sent to reprocessing facilities.

\section{4. - Spent nuclear fuel - composition, radiotoxicity and reprocessing}

The composition of spent nuclear fuel depends on the reactor type, the initial enrichment of U-235 and the burn-up. In table II the average composition of spent nuclear fuel of a standard Pressurised Water Reactor after $33 \mathrm{GWd} / \mathrm{t}$ burn-up and 10 years of cooling is given, ref. [16].

Due to the different half-lives of the radionuclides the overall activity and thus the radiotoxicity changes rapidly with time after discharge. Radiotoxicity is a measure of how noxious a radionuclide is to health. This depends on the type and energy of the ionising radiation, absorption in the organism, residence time in the body, etc. Figure 4, ref. [17], shows the radiotoxicity of $1 \mathrm{t}$ of heavy metal (i.e. the fuel bundle) from a pressurised water 

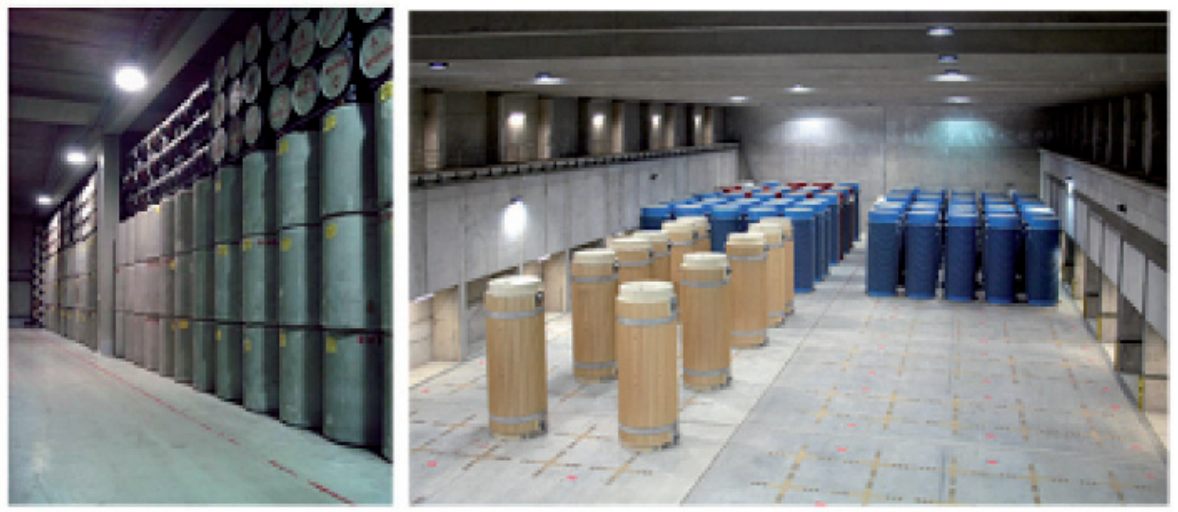

Fig. 3. - Left: Interim storage of LLW/ILW by COVRA at Borssele, The Netherlands; source: [14]. Right: An array of dry casks of HLW at the German interim storage facility of Gorleben; source: [15].

reactor (initial enrichment 4.2\% U-235, burn-up $50 \mathrm{GWd} / \mathrm{t}$ ) with regard to ingestion as a function of time after discharge. In the left-hand frame the contribution of fission products $(\mathrm{FP})$, plutonium $(\mathrm{Pu})$ and minor actinides $(\mathrm{MA})$ to the radiotoxicity is given in detail. In the right-hand frame the modification of the radiotoxicity due to separation of $\mathrm{U}, \mathrm{Pu}$, on the one hand, and $\mathrm{U}, \mathrm{Pu}, \mathrm{MA}$, on the other hand, is shown. The reference

TABLE II. - Average composition of $1 t$ of spent nuclear fuel of a standard Pessurised Water Reactor after 33 GWd/t burn-up and 10 years of cooling. Source: [16].

\begin{tabular}{llll}
\hline Nuclide & Half-life & Mass $/ \mathrm{kg}$ & Remarks \\
\hline $\mathrm{U}$ & & 955.4 & $<1 \%$ U-235 \\
$\mathrm{Pu}-239$ & $2.41 \cdot 10^{4} \mathrm{a}$ & 8.5 & bred from U-238 \\
\hline $\mathrm{Np}-237$ & $2.14 \cdot 10^{6} \mathrm{a}$ & 0.5 & bred from U-238 \\
$\mathrm{Am}-241,243$ & $432.2 \mathrm{a}, 7370 \mathrm{a}$ & 0.6 & bred from U-238 \\
$\mathrm{Cm}-244$ & $18.1 \mathrm{a}$ & 0.02 & bred from U-238 \\
\hline $\mathrm{I}-129$ & $1.57 \cdot 10^{7} \mathrm{a}$ & 0.2 & fission product \\
$\mathrm{Tc}-99$ & $2.11 \cdot 10^{5} \mathrm{a}$ & 0.8 & fission product \\
Zr-93 & $1.53 \cdot 10^{6} \mathrm{a}$ & 0.7 & fission product \\
$\mathrm{Cs}-135$ & $2.30 \cdot 10^{6} \mathrm{a}$ & 0.3 & fission product \\
\hline Cs-137 & $30.17 \mathrm{a}$ & 1.0 & fission product \\
Sr-90 & $28.79 \mathrm{a}$ & 0.7 & fission product \\
\hline Lanthanides & stable & 10.1 & fission products \\
Other & stable & 21.8 & fission products \\
\hline
\end{tabular}



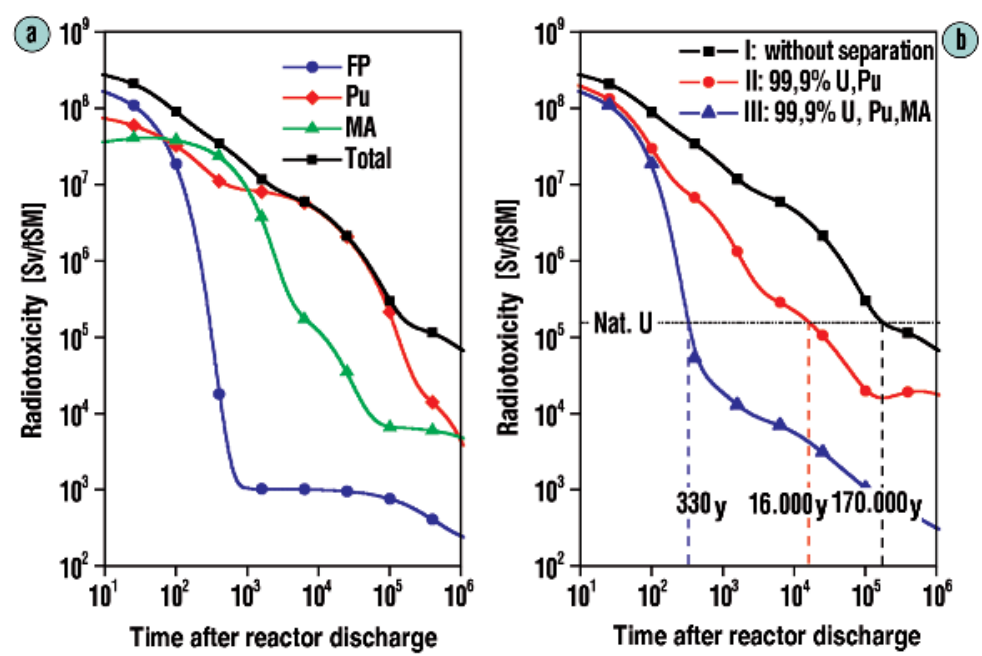

Fig. 4. - Radiotoxicity (log-scale, unit: Sv/tSM) of $1 \mathrm{t}$ of heavy metal (SM) from a pressurised water reactor (initial enrichment $4.2 \% \mathrm{U}-235$, burn-up $50 \mathrm{GWd} / \mathrm{t}$ ) with regard to ingestion as a function of time (log-scale, unit: years) after discharge. Left-hand frame: contribution of fission products $(\mathrm{FP})$, plutonium $(\mathrm{Pu})$ and minor actinides $(\mathrm{MA})$ to radiotoxicity. Right-hand frame: Modification of radiotoxicity due to separation of $\mathrm{U}, \mathrm{Pu}$ or $\mathrm{U}, \mathrm{Pu}, \mathrm{MA}$. The reference value is the radiotoxicity of the amount of natural uranium that was used to produce $1 \mathrm{t}$ of nuclear fuel. Source: [17].

value is the radiotoxicity of the amount of natural uranium that was used to produce $1 \mathrm{t}$ of nuclear fuel.

It is obvious from the left-hand frame of this figure that, until several decades after discharge, fission products dominate the radiotoxicity of spent fuel. However, this contribution decreases rapidly and reaches a level below that of natural uranium at about 330 years. Fission products do not constitute a real problem for long-term storage - $\mathrm{Pu}$ and MA present the major challenge for safe storage in the long run as the radiotoxicity of the MA dominates for several thousand years, and after that $\mathrm{Pu}$ takes over. Only after 170000 years does the spent fuel's radiotoxicity drop below that of natural uranium.

The policy of many countries that run nuclear reactors is to apply a "once through cycle". That means that spent fuel elements as a whole need to be finally disposed of as HLW for 170000 years. Hence, according to table II one needs to dispose of $1 \mathrm{t}$ of HLW (in the form of heavy metal) in order to get rid of $13.3 \mathrm{~kg}$ of fission products, $\mathrm{Pu}$ and MA. The right-hand frame of fig. 4 shows the effect of separating $\mathrm{U}$ and $\mathrm{Pu}$ at a level of $99.9 \%$; such a value is currently reached in modern reprocessing facilities as the one in La Hague, France. In this case the radiotoxicity of the remaining HLW drops below that of natural uranium after 16000 years. The amount of HLW (MA, fission products) which need to be stored or disposed of is only $0.48 \%$ of the original mass of the heavy-metal involved. The separated uranium and plutonium is recycled and used as "mixed oxide" 


\section{LNES2012}

(MOX) fuel in power plants. If one succeeds in separating $\mathrm{U}, \mathrm{Pu}$ and $\mathrm{MA}$ at a level of $99.9 \%$ then, according to the right-hand frame of fig. 4 , the remaining radiotoxicity drops below that of natural uranium after 330 years already - this is a historical period, not a geological one and safe storage and disposal is possible without encountering major problems. The amount of HLW (fission products) which needs to be stored or disposed of is only $0.37 \%$ of the original mass. Separation of MA, however, is reasonable only if nuclear reactors of Generation IV or accelerator-driven systems for transmutation will be built that can burn or transmute MA and thus make their long-term storage dispensable.

At present about 400000 tonnes of heavy metal (accumulated since the first reactor was put into operation) were discharged worldwide, one quarter of which was reprocessed whereas three quarters are stored on site or at interim storage facilities. In view of the arguments just given one must conclude that the disposal of spent fuel elements as a whole as HLW after a "once through cycle" is clearly inferior to the disposal of HLW left over after extracting both $\mathrm{U}$ and $\mathrm{Pu}$.

\section{5. - Disposal options $\left({ }^{3}\right)$}

The main objective in managing and disposing of radioactive (and other) waste is to protect people and the environment. For this reason, waste must be isolated, both from human activity and dynamic natural processes, to such a degree that possible releases of radionuclides only occur in such low concentrations as to not pose a hazard to human health and the environment. In order to achieve this, virtually all waste is conditioned, packaged and managed as described above. The particular way of disposing radioactive waste, then, depends on the waste's level of radioactivity, the half-life of the radionuclides, and also on the amount of generated heat.

Two management procedures are commonly accepted: Firstly, near-surface disposal of LLW containers at ground level in constructed vaults, which are backfilled when full and covered with a protective layer measuring a few metres (implemented in the Czech Republic, Finland, France, Japan, The Netherlands, Spain, Sweden, UK and USA) or in caverns at depths of tens of metres (implemented in Finland and Sweden for LLW and short-lived ILW). These methods have been used routinely and safely for over fifty years. Figure 5 shows the French disposal facility Centre de l'Aube for LLW and ILW [21].

The second procedure, which is the preferred means of disposal of high level waste and long-lived radionuclides, is deep geological disposal at depths between 250 and $1000 \mathrm{~m}$ using a system of natural and engineered barriers (multi-barrier concept). The geological formation in which the waste is emplaced, referred to as "host rock", generally constitutes the most important isolation barrier. Engineered barriers refer to containers or canisters into which the conditioned waste is placed; any overpack above; the backfill/buffer material immediately surrounding the waste package (e.g. cement, bentonite); as well as

$\left({ }^{3}\right)$ This chapter is based on publications of the International Atomic Energ Agency, IAEA [18-

20] and the World Nuclear Association, WNA [6]. 


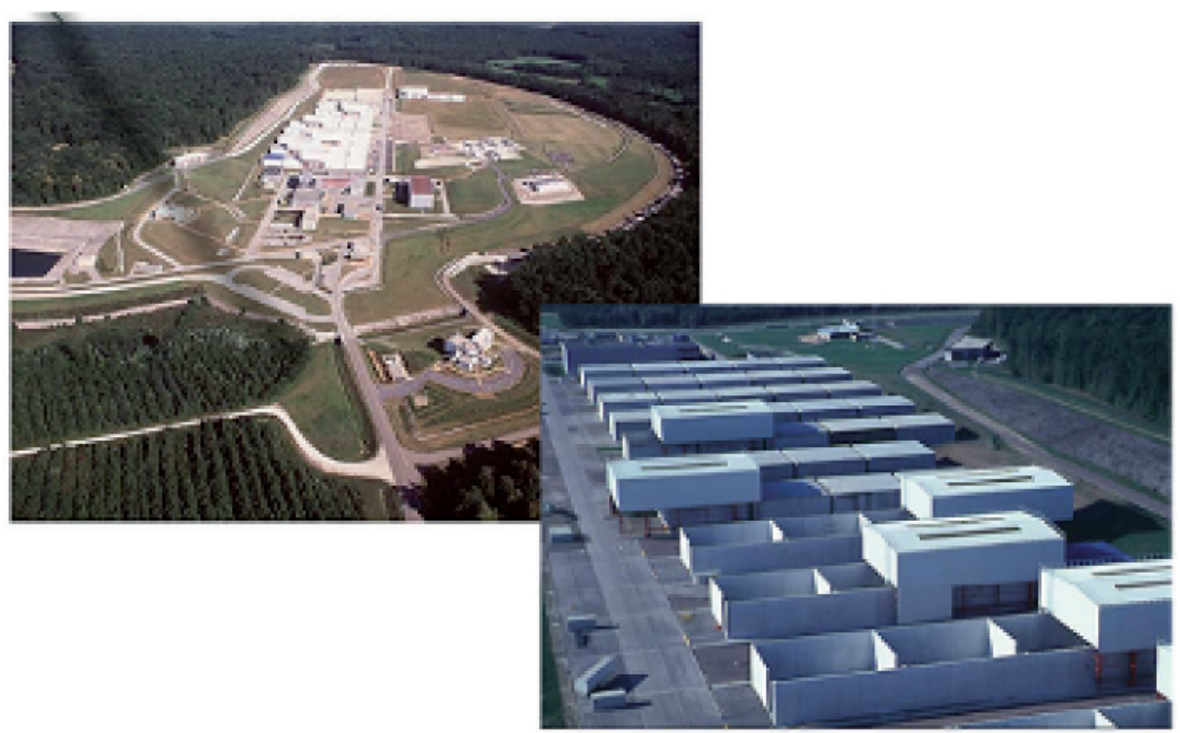

Fig. 5. - The French disposal facility Centre de l'Aube for LLW and ILW [21].

the repository mass backfill in and surrounding the region used for waste emplacement. Figure 6 shows a sketch of how the multi-barrier concept for deep geological disposal is going to be implemented by SKB, the Swedish Nuclear Fuel and Waste Management Company [22].

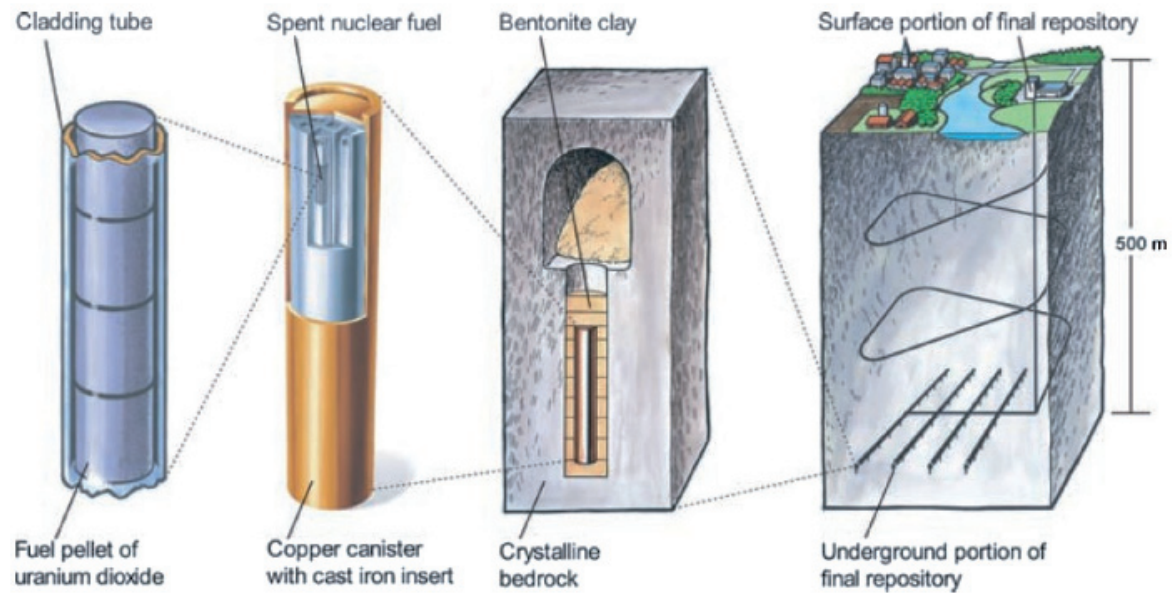

Fig. 6. - The concept of SKB, the Swedish Nuclear Fuel and Waste Management Company, for the disposal of spent nuclear fuel illustrates one multi-barrier concept. Source: [22]. 
Scientific and technical studies of geological disposal have addressed all issues that need to be considered, among them

- the characteristics of the host rock (in particular granite and gneiss, consolidated and plastic clays, rock salts (layered salt strata or salt domes) or tuff) with regard to rock mechanics and repository construction requirements,

- the near-field environment and processes therein. These depend on the groundwater environment, in particular the flow rate and chemistry; waste form; container material; backfill material; construction material inside the repository; mobilisation of radionuclides as well as gas production and its consequences,

- the far-field barriers and processes therein. These depend on groundwater pathways; hydrogeology and water movement; water chemistry and chemical retardation; long-term tectonic stability and the potential impact of the climate change.

In this context, the heat generated by radioactive waste is of major importance: An increase in temperature may cause the host rock to swell possibly leading to faults and dislocations which, in turn, adversely affect the host rock's hydrology or, in the worst case, its tectonic stability. Rising temperatures, in general, also accelerate chemical processes such as corrosion and gas production, and also increase the solubility and mobility of chemical compounds. The studies underline that sound technical solutions are available for a concept of geological disposal that inhibits the emergence of radionuclides into the biosphere during the given time period.

Figure 7 shows an example of a suitable geological formation: the German ILW disposal facility "Schacht Konrad" currently under construction (to be operational in 2014) [23]. It is located in an abandoned iron ore mine $800-1300 \mathrm{~m}$ below the surface and covered by a $400 \mathrm{~m}$ thick layer of clay. There are no hydraulically effective pathways to near-surface groundwater. The various homogeneous strata above and below the iron ore mine are 60 to 200 million years old. The repository is believed to meet all requirements with regard to the technical and geological barriers necessary to guarantee a containment of radioactive waste for millions of years.

Several countries are preparing to construct deep geological repositories as their method of choice for the final disposal of radioactive waste. Preferred sites for HLW/spent fuel repositories have been selected in France, Finland and Sweden. The selection process, which identified three sites as equally suited, was completed in Switzerland; the decision on the final site is pending. Site selection has commenced in Canada and the USA. As a result of the German nuclear phase-out programme, the exploration of the Gorleben salt dome, which has been selected as the German HLW repository, came to a halt; unbiased studies of other types of geologic formations are supposed to be carried out in the future. As yet, only the Waste Isolation Pilot Plant (WIPP) in the Chihuahuan Desert, outside Carlsbad, NM, USA is operational [24]. The repository was constructed within a $600 \mathrm{~m}$ thick salt basin covered by $300 \mathrm{~m}$ of soil and rock. It is dedicated to disposal of defence-related transuranic waste (TRU: Pu and MA). WIPP has been operational since March 1999.

A variant of deep geological disposal is the deep borehole option. Deep boreholes are drilled from the surface to depths of several kilometres into crystalline or sedimentary host 


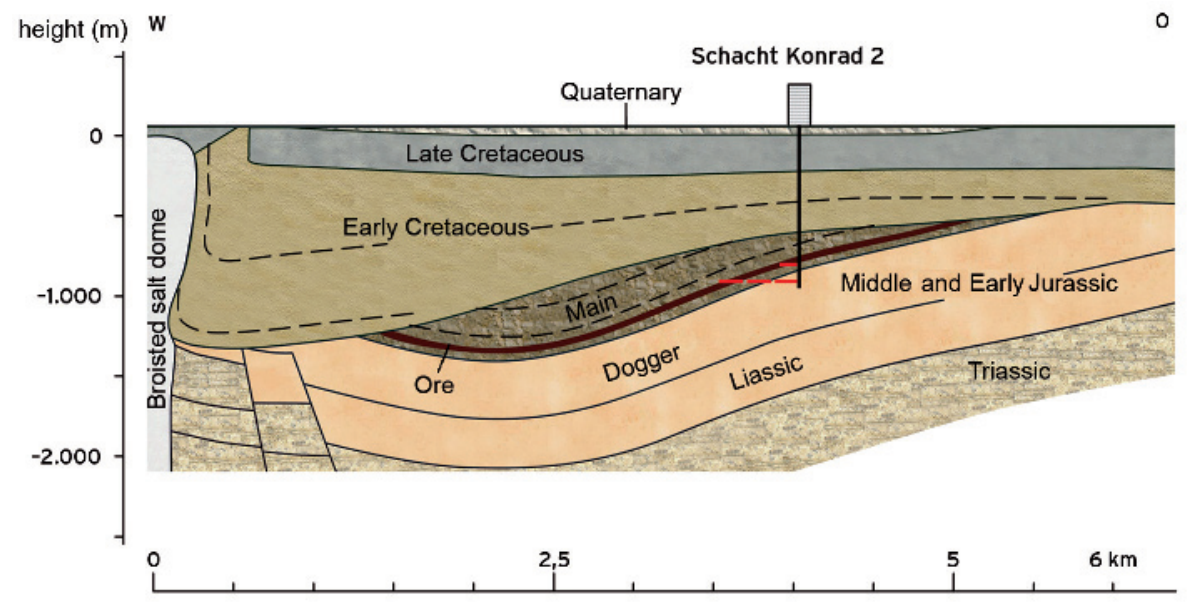

Fig. 7. - The geological formation of the German ILW disposal facility "Schacht Konrad" currently under construction. To be operational in 2014. Source: [23].

rocks. Waste containers are stacked inside this borehole and separated from each other by layers of bentonite or cement. The top two kilometres of the borehole are sealed with bentonite, cement or asphalt. This concept was developed in, e.g., Denmark, Finland, Sweden, Switzerland and the USA for HLW and spent fuel, but not implemented as it was found to be too expensive should large volumes need to be disposed of. However, it remains an attractive option for the disposal of sealed radioactive sources used in medical and industrial applications [25].

A very specific version of deep borehole disposal is the so-called high-temperature deep borehole disposal. This option is intended for HLW for which the accumulated heat is high enough to melt the surroundings and dissolve the radionuclides in a sphere of molten material. After cooling and solidification the radionuclides are incorporated into the rock matrix and, thus, are immobilised. This procedure, studied e.g. in Russia, the UK and the USA, is depicted in fig. 8. It has not been implemented anywhere yet but research into this option still continues.

Many other options were studied in the past: disposal in outer space; at sea; in the sub-sea bed; in subduction zones; in ice sheets. They have never been implemented and have been prohibited by international agreements. The method of direct injection was implemented in the former Soviet Union and the USA. It makes use of a porous layer of host rock located between impermeable layers that act as a natural seal both horizontally and vertically. Liquid radioactive waste is then injected into the porous layer, that soaks it up like a sponge and accommodates it. This method was abandoned.

For the sake of completeness we will briefly address the timeline illustrating the development of a geological disposal. It can be roughly divided into three periods: the pre-operational, the operational and post-operational phase. The first starts with the 


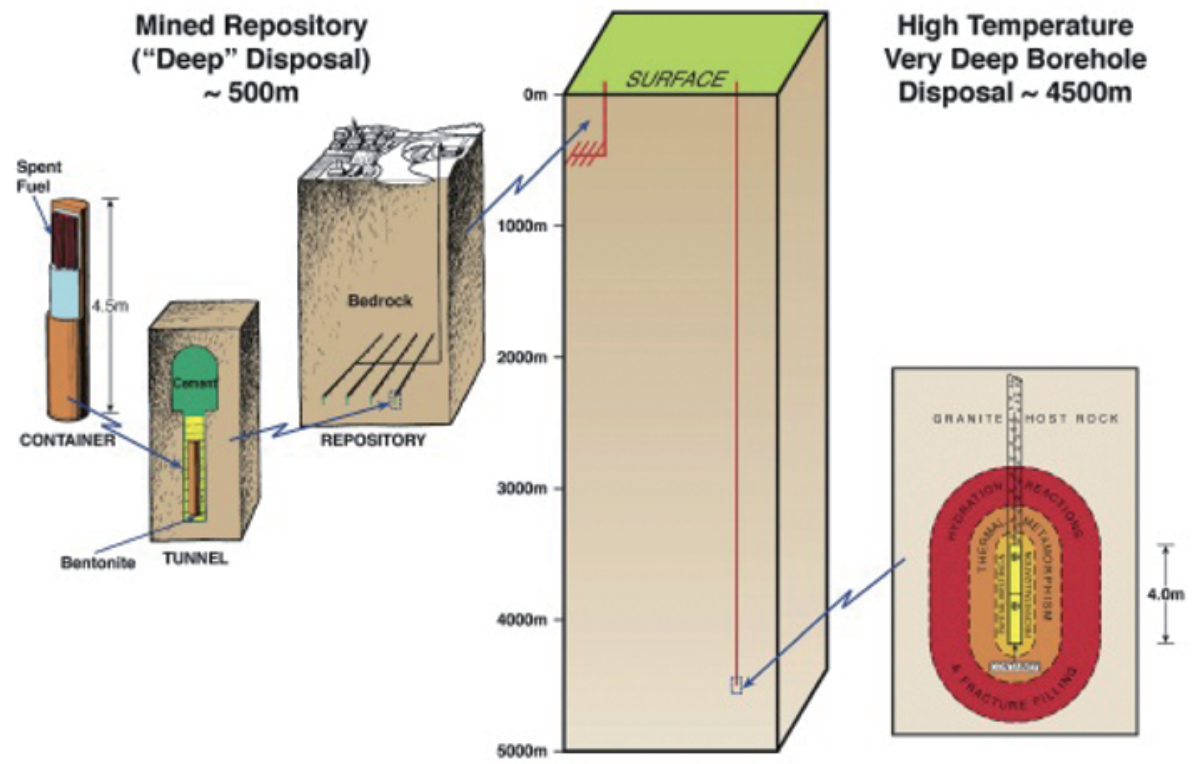

Fig. 8. - Very-deep borehole disposal, The University of Manchester, Dalton Nuclear Institute, courtesey of Dr. John Roberts.

decision to select a suitable site (see site-selection criteria discussed above). Based on the safety and performance assessments as well as the development of monitoring and testing programmes, which are an integral part of the pre-operational period, the decision to construct the repository is made by the regulatory authorities. The period of the early construction activities, which are permanently monitored, ends with the regulatory decision to emplace radioactive waste. The operational period begins with the first emplacement. After this step, the management activities include not only emplacement but also radiation control and surveillance. The constant monitoring of the status of the repository forms the basis for decisions on pending emplacements as well as further construction of additional drifts, shafts or chambers and for the final sealing of fully loaded parts of the facility. This step-by-step process enables one to incorporate new knowledge and scientific and/or technical/technological developments. On this basis, earlier decisions regarding the repository can be confirmed, modified or reversed, such as waste retrieval. Being able to retrieve waste is important as spent fuel elements still contain a significant amount of fissionable material which can be reprocessed if fresh fuel is lacking. It is also conceivable that new methods will be developed over time (such as partitioning and transmutation) that could effectively reduce the amount of radioactive material to be disposed of and the amount of time required for its safe disposal. However, it is common understanding that the ability to retrieve HLW must not be bought by relaxing safety standards or requirements, it must not be permitted to have adverse effects on the safety or performance of a repository. Whether the retrievability is intended or not depends on 
the policy adopted by the individual states and their approach is rather inconsistent.

After the intended operational period, which may last for several decades, the regulatory decision to close the repository is made. The post-operational period begins with putting the repository into its final phase (setting all engineered barriers, decommissioning operational buildings and maintaining services). The goal of all final disposal projects is to guarantee passive safety after closure. That means that no measures need to be actively taken to assure the safety of the closed repository. Nevertheless, institutional control and environmental monitoring is intended for a certain period of time but not forever. A major concern regarding the post-operational period is the preservation of detailed knowledge over many centuries about the repository's location and inventory. Initial solutions to this problem have been implemented at WIPP [24]. It is conceivable that human activities that changed the surface of the Earth considerably in the past may also do so in the future. However, human intrusion into a geological repository, unauthorised or inadvertently, must be prevented and/or made near-impossible by appropriate measures. Whether it should be possible or not to re-open a closed repository in an authorised procedure to recover radioactive material remains open to debate.

\section{6. - The role of the International Atomic Energy Agency}

"The IAEA's Statute authorizes the Agency to establish safety standards to protect health and minimize danger to life and property - standards which the IAEA must use in its own operations, and which a State can apply by means of its regulatory provisions for nuclear and radiation safety" (cited from ref. [26]) "The IAEA does this in consultation with the competent organs of the United Nations and with the specilized agencies concerned. A comprehensive set of high quality standards under regular review is a key element of a stable and sustainable global safety regime, as is the IAEA's assistance in their application" (cited from ref. [27]). The IAEA has provided the Safety Standards Series which reflects an international consensus on what constitutes a level of safety for protecting people and the environment from harmful effects of ionising radiation. These safety standards consist of three categories as shown in table III, ref. [27]. The first category is called Safety Fundamentals/Fundamental Safety Principles. These fundamentals/principles represent the safety objectives and principles of safety and protection which, in turn, provide the basis for the second category, the so-called General and Specific Safety Requirements which are detailed in the central part of table III.

The third category, the so-called Collection of Safety Guides, provides recommendations and guidance on how to comply with the general and specific safety requirements just mentioned. In addition, the Technical Report Series describes the scientific and technical basis for all fields for which general and specific safety requirements are formulated.

The safety standards are only effective if they are adopted by national authorities that also adhere to those standards. In order to establish a legal basis, the "Joint Convention on the Safety of Spent Nuclear Fuel Management and the Safety of Radioactive Waste Management" was adopted on 5 September 1997 [28] and came into effect on 18 June 
TABLE III. - The long-term structure of the IAEA Safety Standards Series. Source: [27].

Safety Fundamentals
Fundamental Safety Principles

\begin{tabular}{|c|c|}
\hline General Safety Requirements & Specific Safety Requirements \\
\hline $\begin{array}{l}\text { Part 1. Governmental, Legal and } \\
\text { Regulatory Framework for Safety }\end{array}$ & $\begin{array}{l}\text { 1. Site Evaluation for Nuclear } \\
\text { Installations }\end{array}$ \\
\hline Part 2. Leadership and Management for Safety & $\begin{array}{l}\text { 2. Safety of Nuclear Power Plants } \\
\text { 2.1 Design and Construction }\end{array}$ \\
\hline $\begin{array}{l}\text { Part 3. Radiation Protection and the } \\
\text { Safety of Radiation Sources }\end{array}$ & 2.2 Commissioning and Operation \\
\hline $\begin{array}{l}\text { Part 4. Safety Assessment for } \\
\text { Facilities and Activities }\end{array}$ & $\begin{array}{l}\text { 3. Safety of Research Reactors } \\
\text { 4. Safety of Nuclear Fuel Cycle } \\
\text { Facilities }\end{array}$ \\
\hline Part 5. Redisposal Management of Radioactive & 5. Safety of Radioactive Waste \\
\hline $\begin{array}{l}\text { Part } 6 \text {. Decommissioning and } \\
\text { Termination of Activities }\end{array}$ & $\begin{array}{l}\text { Disposal Facilities } \\
\text { 6. Safe Transport of Radioactive }\end{array}$ \\
\hline Part 7. Emergency & Material \\
\hline
\end{tabular}

\section{Collection of Safety Guides}

2001; at present 63 states are members of the Joint Convention. Its objectives are to achieve and maintain a high level of safety worldwide by means of national measures and international cooperation; to ensure effective and sustainable defences against potential hazards of ionising radiation; to prevent accidents with hazardous radiological consequences and to mitigate them should they occur. Part of this convention is a review process. Each party to the Joint Convention must demonstrate that it fulfils its international obligations by providing a national report on the status of the implementation of the Joint Convention to all other parties every second or third year. Written questions and answers to any report of the Contracting Parties are intended to clarify open questions and problems. These reports are then presented and discussed at Review Meetings, the fourth of which took place in Vienna, 14-23 May 2012, ref. [29].

IAEA also carries out peer reviews on the safety of radioactive waste management and storage facilities on request by a contracting party. These peer reviews, which are published (e.g., [14]), are acknowledged as an important means to build confidence in the safety of nuclear facilities. 


\section{7. - Closing remark}

In view of the many national activities, their promising progress and international cooperation with regard to the final disposal of radioactive waste, the outlook on the implementation of safe repositories for LLW, ILW and HLW worldwide within the next few decades is promising.

$$
* * *
$$

This paper has resulted from stimulating discussions within the Energy Group of the European Physical Society. They are gratefully acknowledged.

\section{REFERENCES}

[1] "Naturally Occurring Radioactivity (NORM IV)", Proceedings of an International Symposium, Marrakesh, Marocco, 22-26 March 2010.

[2] World Nuclear Association: http://www . world-nuclear.org/info/inf30.html $\left({ }^{4}\right)$.

[3] http://www.tenorm.com/sectors.htm.

[4] US Environmental Protection Agency: http://www.epa.gov/radiation/tenorm/sources.html.

[5] IAEA Safety Standards, Classification of Radioactive Waste, General Safety Guide, No. GSG-1.

[6] World Nuclear Association: Radioactive waste management, http://www . world-nuclear.org/info/inf04.html.

[7] International Basic Safety Standards, Radiation Protection and Safety of Radiation Sources, IAEA General Safety Requirements, GSR Part 3.

[8] Compaction of Radioactive Waste, NUKEM Technologies GmbH 2007.

[9] Incineration of Radioactive Waste, NUKEM Technologies GmbH 2007.

[10] Cementation of Radioactive Waste, NUKEM Technologies GmbH 2007.

[11] British Nuclear Fuels Limited: http://mrws.decc.gov.uk/en/mrws/cms/Home/What_is_radiow/What_is_radiow.aspx.

[12] Report of the Federal Republic of Germany for the Third Review Meeting in May 2009 (in response to the "Joint Convention on the Safety of Spent Nuclear Fuel Management and the Safety of Radioactive Waste Management" IAEA INFCIRC/546 24 December 1997) http://www.bmu.bund.de/atomenergie_ver_und_entsorgung/ internationale_zusammenarbeit/doc/42445.php.

[13] World Nuclear Association, Synrock Wasteform: http://www. world-nuclear.org/info/inf58.html.

[14] IAEA Safety Standards Applications Series No. 8, Peer Review of the Radioactive WasteManagement Activities of COVRA, Netherlands.

[15] Gesellschaft für Nuklear-Service mbH, http://www.gns.de.

[16] "Physics and Safety of Transmutation Systems. A Status Report", OECD 2006, NEA No. 6090. ISBN 92-64-01082-3.

[17] Geist A. et al., Nachrichten - Forschungszentrum Karlsruhe Jahrg., 36 (2004) 97-102; http://bibliothek.fzk.de/zb/veroeff/58263.pdf.

$\left({ }^{4}\right)$ All URLs last retrieved on 27 July 2012. 


\section{LNES2012}

[18] "Scientific and Technical Basis for the Near Surface Disposal of Low and Intermediate Level Waste", IAEA Technical Report Series TRS-412.

[19] "Scientific and Technical Basis for the Geological Disposal of Radioactive Waste", IAEA Technical Report Series TRS-413.

[20] "Considerations in the Development of Near Surface Repositories for Radioactive Waste", IAEA Technical Report Series TRS-417

[21] ANDRA (Agence Nationale pour la Gestion des Déchets Radioactifs) http://www . andra.fr/andra-aube/.

[22] Svensk Kärnbränslehantering AB, (SKB Swedish Nuclear Fuel and Waste Management Co) http://www.skb.se.

[23] http://www.endlager-konrad.de/cln_351/nn_1073436/SharedDocs/Downloads/DE/ Konrad_Leporello.html.

[24] Waste Isolation Pilot Plant; http://www.wipp.energy.gov/index.htm.

[25] "Disposal Options for Disused Radioactive Sources", IAEA, Technical reports series, STI/DOC/010/436 (July 2005).

[26] IAEA Safety Standards; Fundamental Safety Principles: Safety Fundamentals, No. SF-1.

[27] IAEA Safety Standards; Geological Disposal Facilities for Radioactive Waste. Specific Safety Guide, No. SSG-14.

[28] "Joint Convention on the Safety of Spent Nuclear Fuel Management and the Safety of Radioactive Waste Management", IAEA INFCIRC/546.

[29] Fourth Review Meeting on the Joint Convention, Vienna, 14-23 May 2012, JC/RM4/04/ Rev.2. 